\title{
Prevalence of Monogenean Helminth Ectoparasites on Catfish (Clarias gariepinus) Culture Ponds in Laban Village, Menganti District, Gresik Regency, East Java Province
}

\author{
Sri Subekti Bendryman ${ }^{1}$, Adelina Grace ${ }^{2}$ and Eduardus Bimo Aksono ${ }^{3}$ \\ ${ }^{1)}$ Department of Veterinary Parasitology, ${ }^{2)}$ Department of Veterinary Anatomy, ${ }^{3)}$ Department of Basic \\ Veterinary Medical Science, Faculty of Veterinary Medicine Airlangga University, Indonesia
}

\begin{abstract}
The aims of this study are to know the prevalence of monogenean helminth ectoparasites infection on catfish culture, to know determine the number of monogenean infection on 100 samples consists of 1 and 3 months old of catfish. This study was conducted on May to June, 2011 in catfish culture ponds, Laban Village Menganti District and Gresik Regency, East Java Province. The methods were used in this research were skin and gill scrapping. The data were analyzed by using chi square test with SPSS program version 18.0 for windows. The results showed that prevalence of monogenean in catfish culture ponds, Laban Village Menganti District Gresik Regency, East Java Province was 32\%. The highest infection was in the young catfish compared with the older ones with percentage of $23 \%$ and $9 \%$ respectively and based on chi square test showed that there were a very significantly differences $(\mathrm{p}<0.01)$.
\end{abstract}

Key words: Monogenean, Clarias gariepinus, prevalence, helminth ectoparasites

\section{Introduction}

Catfish (Clarias spp.) is one of freshwater fish that were commercially cultured by Indonesian peoples especially in Java. The development of Catfish culture is very fast they could be cultured in limited areas and water sources with high density spread, cultured technology relatively easy to apply, sell and with minimized capital by people. Development of catfish culture effort too increased after African Catfish (Clarias gariepinus) enter to Indonesia in 1985, Africa Catfish is crossing-mating between African and Taiwan Catfish. African catfish is omnivore that eat plankton, worm, insectam small crustacea (Usni et al., 2010; Akinsanya and Otubanjo, 2005).

African catfish (Clarias gariepinus) was wellknown as freshwater fish that resistant to disease, therefore bad feed quality, wrong feeding and management could caused African catfish became susceptible to disease. According to Gufran (2004) the attact of disease is a big problem that was considered as barrier fish cultured, because disease caused longer breeding periods, high feed conversion, low spread density and mortality. Disease that attacted fish were influenced by relation among three factors as follows environment, host and pathogenic organisms, and disease that attacted these fishes showed ecosystem unstabilized.

Parasitic disease is infectious disease that often attacted fish. One of parasitic disease in African catfish was caused by trematodes especially ordo Monogenea (Hendriana, 2010). Monogenean ectoparasitic helminth that often attacted freshwater fish including African catfish as follows Gyrodactylus sp. and Dactylogyrus sp. Monogenean ectoparasite attacted young and adult fishes. Transmisssion happened through water and directly contact between infected fish and healthy fish. Supporting factor of Monogenean development are water quality decreased, high density of fish population, changement of water temperature, and food 
deficiency (Bambang, 200o). There were catfish culture some years ago at Menganti sub district, Gresik District East Java Province, because the stability of temperature in this area. Murugaian (2008) stated that temperature is one of factors that influenced in fish development process, also influenced to fish immune system (Ghufran, 2004).

The study used African catfish with one and three months old. This difference was choosed by one month old of African catfish is young group and three months of African catfish is adult group. Irianto (2005) stated that one of factors that influenced fish immune system vis-a-vis pathogenic attacted is age factor.

According to background, the research was done concerning ectoparasites prevalence of Monogenean (Gyrodactylus sp. and Dactylogyrus $s p$ ) in African catfish (Clarias gariepinus) in catfish culture pond in Menganti District, Gresik Regency, East Java Province.

\section{The objective of study}

The objective of this study is to know Monogenean ectoparasite prevalence (Gyrodactylus sp. and Dactylogyrus sp.) in African catfish (Clarias gariepinus) in catfish culture pond at Laban Village, Menganti District, Gresik Regency, East Java Province, the difference between infected African catfish population with one and three months old, and the difference between infected catfish population in superficial body and gills.

\section{Materials and Methods}

\section{Time and Location of the research}

The research was done at catfish culture pond in Laban Village, Menganti District, Gresik Regency, on May - June, 2011. Samples were observed at Parasitology Department, Faculty of Veterinary Medicine Airlangga University Surabaya.

\section{Sampels}

100 sampels of life African catfish (Clarias gariepinus) were used with one month old (9-12 $\mathrm{cm}$ of body length) and three months old (14-20 cm of body length), from catfish culture pond at Laban Village, Menganti District and Gresik Regency, East Java Province.

Materials of research that were used as follows: aquarium, plastic suc, fish net, Petri dish, scalpel, spatula, pinset, object glass, cover glass, binocular microscope, scalpel, dissecting microscope, and Pasteur pipette. Reagents: alcohol 70\%, aquadest, formalin $10 \%$ and Carmine staining solution.

The research was done with taking randomized samples from two catfish culture ponds of aquaculturists. The African catfish (Clarias gariepinus) one month old $(9-12 \mathrm{~cm}$ of body length) and three months old $(14-20 \mathrm{~cm}$ of body length), was taken 25 fish each pond from these catfish culture ponds at Laban Village, Menganti District Gresik Regency.

The African catfish population of A ponds were $1500-2000$ fish $/ 1.4 \mathrm{~m}^{2}$ with one month old and 1000-1500/1.5 $\mathrm{m}^{2}$ with three months old and of $B$ ponds were $1000-1500 \mathrm{fish} / 2 \mathrm{~m}^{2}$ with one month old and 1000-200o fish $/ 1.8 \mathrm{~m}^{2}$. Total of samples were 100 catfishes. Life samples of catfishes were taken by using net, then were collected in closed suc plastic content with pond water and oxygenized (Langdon dan Jones, 2002 in Abo-Esa, 2008). Samples'were brought at Parasitology Department, Faculty of Veterinary Medicine, Airlangga University, transferred to aquarium and were observed monogenean ectoparasites (Gyrodactylus sp. and Dactylogyrus sp.) to identify.

\section{Observation by using scrapping method}

Skin mucous and gills of catfish was taken by using scrapping put on object glass, added one drop of aquadest and covered with coverglass. Observation was done by binocular microscope with 40ox (Noga, 200o) to identify monogenean ectoparasites.

\section{Observation of pond water quality}

Observation pond water quality was done with temperature analyzed and $\mathrm{pH}$ in pond water. 


\section{Semichon's Acetocarmine staining method}

Semichon's Acetocarmine was used to helminth identify (Kusumamihardja, 1995 in Hariyadi, 2006). Specimen staining was done by dipping in acetocarmine solution and was done dehydration by steps of alcohol before fixed on object glass.

Data was analyzed by total of infested fish were compared with total of investigated fish (\%).

Data was analyzed by using chi-square with SPSS program (Statistical Program for Social Scientific) versi 18.0 for windows to compare monogenean ectoparasite prevalence (Gyrodactylus sp. Dan Dactylogyrus sp.) between one month old of and three months old of African catfish.

\section{Results and Discussion}

The result showed that prevalence of monogenean ectoparasites (Gyrodactylus sp.dan Dactylogyrus sp.) was 32\% (Tabel 1). Tabel 1 showed that samples from one month and three months old of African catfish respectively were $23 \%$ and $9 \%$ positive infested monogenean ectoparasites (Gyrodactylus sp and Dactylogyrus sp.).

Table 1. Monogenean Ectoparasites (Gyrodactylus sp. and Dactylogyrus sp.) in African Catfish at Laban Village, Menganti District, Gresik Regency, East Java Province

\begin{tabular}{cccc}
\hline \multirow{2}{*}{ Age } & \multicolumn{2}{c}{ Infestation (\%) } & \multirow{2}{*}{ Total } \\
\cline { 2 - 3 } & Positive & Negative & \\
\hline 1 month & 23 & 27 & 50 \\
3 months & 9 & 41 & 50 \\
\hline Total & 32 & 68 & 100 \\
\hline
\end{tabular}

The data was analyzed by using Chi-Square, showed there were very significantly difference ( $\mathrm{p}<\mathrm{o} .01)$ between Monogenean ectoparasites (Gyrodactylus sp. and Dactylogyrus sp.) with one month and three months old of African catfish.

Table 2. Infestation of Monogenean Ectoparasites (Gyrodactylus sp. and Dactylogyrus sp.) in Skin and Gills of African Catfish

\begin{tabular}{cccc}
\multirow{2}{*}{ Predilection } & \multicolumn{2}{c}{ Infestation (\%) } & \multirow{2}{*}{ Total } \\
\cline { 2 - 3 } & Positive & Negative & \\
\hline Skin & 0 & 50 & 50 \\
Gills & 32 & 18 & 50 \\
\hline Total & 32 & 68 & 100
\end{tabular}

Observation in African Catfish skin was not found parasite $(\mathrm{o} \%)$, whereas in gills were found $32 \%$ of monogenean ectoparasite infestation (Gyrodactylus sp. and Dactylogyrus sp.), and was analyzed by using Chi-Square showed very significantly difference $(\mathrm{p}<0.01)$ between monogenean ectoparasite (Gyrodactylus sp. dan Dactylogyrus sp.) in skin and gills of African Catfish at Laban Village, Menganti District, Gresik Regency.

Monogenean ectoparasite prevalence (Gyrodactylus sp. and Dactylogyrus sp., figure 2) was $32 \%$ in gills of fish, composed of $16 \%$ infested by Gyrodactylus sp., 9\% infested by Dactylogyrus sp., and $7 \%$ from mixed infestation, Gyrodactylus sp. and Dactylogyrus sp. (Table 2).

The prevalence of Monogenean ectoparasites (Gyrodactylus sp. and Dactylogyrus sp., figure 2) of African catfish was $32 \%$. The result of this study showed that the prevalence was higher than Diab et al., (2003) study (14.8\%) and Esa (2008) was $25 \%$. Difference result was affected by environmental physically (deep, current, and temperature) and chemical (oxygen and salinity).

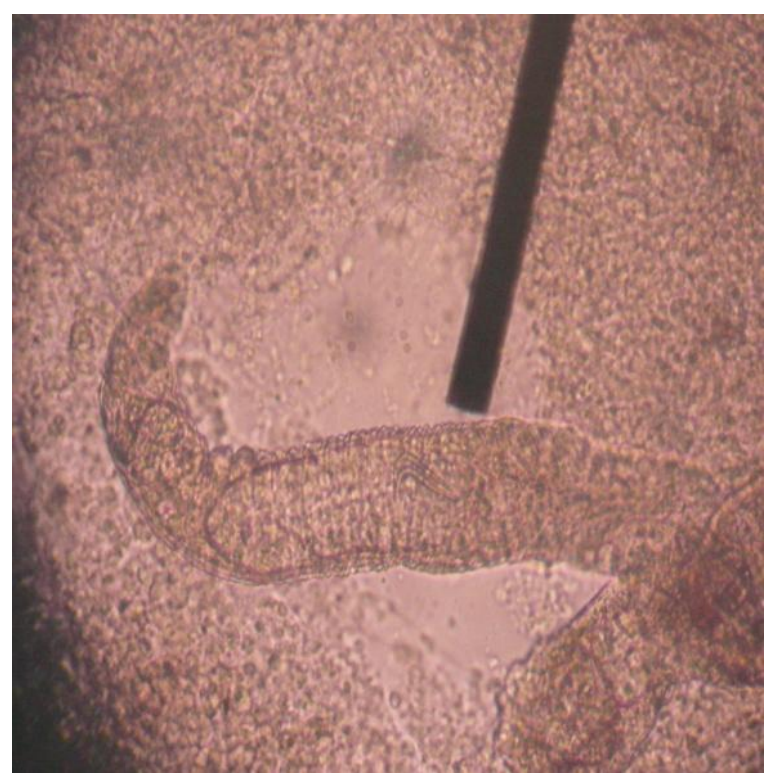

Fig. 1. Monogenean Ectoparasites in African Catfish (Gyrodactylus sp.) (40ox). 


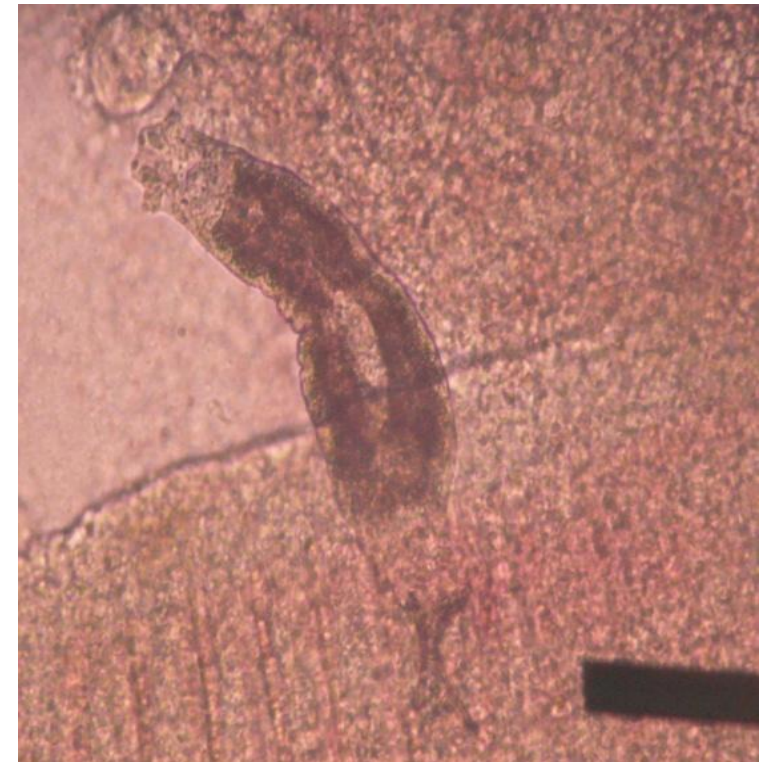

Fig. 2. Monogenean Ectoparasites in African Catfish (Dactylogyrus sp.) (40ox).

Infestation of monogenean ectoparasites (Gyrodactylus sp and Dactylogyrus sp) of African catfish with one month and three months old respectively were $23 \%$ and $9 \%$ and by Chi-Square analysis showed very significantly difference $(\mathrm{p}<0.01)$. The result showed there was response immune difference toward difference age of fish. Irianto (2005) suggested that fish respons immune performed in adult, meanwhile young fish response immune was still not efficiently; therefore they were susceptible toward disease. The difference of prevalence was also caused by different habitual of feeding (Akinsanya and Otubanjo, 2005). Unbalanced feed or too much of component could caused the problem. According to Afrianto and Liviawaty (1992) feeding with low protein content will decrease growth rate, un perfectly of reproduction process, and cause fish get a disease easily.

Table 3. Infestation of Monogenean Ectoparasites (Gyrodactylus sp. and Dactylogyrus sp.) in Gills of African Catfish

\begin{tabular}{lccc}
\hline \multirow{2}{*}{$\begin{array}{l}\text { Infestation of } \\
\text { Ectoparasites }\end{array}$} & \multicolumn{2}{c}{$\begin{array}{c}\text { Positive Sample of } \\
\text { African Catfish (Clarias }\end{array}$} & \multirow{2}{*}{$\begin{array}{c}\text { Total } \\
\text { gariepinus) }\end{array}$} \\
\cline { 2 - 3 } & 1 month & 3 months & \\
\hline $\begin{array}{l}\text { Gyrodactylus sp. } \\
\text { Dactylogyrus sp. }\end{array}$ & 6 & 4 & 16 \\
$\begin{array}{l}\text { Gyrodactylus sp. } \\
\text { and }\end{array}$ & 5 & 3 & 9 \\
$\begin{array}{l}\text { Dactylogyrus sp. } \\
\text { Total }\end{array}$ & $23^{\mathrm{a}}$ & 2 & 7 \\
\hline
\end{tabular}

Table 4. Temperature Parameter and $\mathrm{pH}$ of Culture Pond Water

\begin{tabular}{lccc}
\hline Parameter & Normal & Pond $\mathrm{A}_{1^{*}}$ & Pond $\mathrm{A}_{2^{*}}$ \\
\hline Temperature & $26-30^{\circ} \mathrm{C}$ & $26.5^{\circ} \mathrm{C}$ & $26.5^{\circ} \mathrm{C}$ \\
$\mathrm{pH}$ & $6.5-9$ & $6-7$ & $6-7$ \\
\hline
\end{tabular}

*Remark: $1=$ one month old of fish, $2=$ three months old of fish

Organ observation in African catfish was done in skin and gills, showed there was only gills $32 \%$ positive infested and no infestation in skin (o\%). The result was analyzed by Chi Square test showed there was very significantly difference $(\mathrm{p}<\mathrm{o.01})$. The high ectoparasites infestation in gills can be caused by quantity of erytrocyte were higher than in skin and there were much more oxygen gills than in skin, and gills have a high oxygen content that was needed by organism such as monogenean ectoparasites. Factor of temperature is very influenced to ectoparasite infestation. Skin is first organ that predilection to monogenean ectoparasite, and skin is most external location than other organ, therefore it is most susceptible to temperature changed than other organ. There were two genus of ectoparasites such as Gyrodactylus sp. and Dactylogyrus sp.infested to African catfish. The heavy infestation of ectoparasites can cause asphyxia (Subekti and Mahasri, 2010). Patologic changed in skin and gills, such pale skin, damage of gills, a lot of mucous and weak movement. Besides that, fish became slow of growth, loss of weight, appetite decrease, behaviour changed such as flashing and appear to water surface caused by respiratory problem (Reed et al., 2005)

Ponds water qualities showed that temperature and $\mathrm{pH}$ of each pond was different. The difference of temperature and $\mathrm{pH}$ give effect to distribution of monogenean ectoparasites in African catfish. The high temperature and $\mathrm{pH}$ in ponds caused less of oxygene in fish and caused stress. Stress was a factor caused fish more susceptible to disease Reddy and Leatherland (1998) suggested that stress was industurbable condition of homeostasis in fish caused by instabilisation of environment. 
Effect of stress to immunity decreased of fish taken placed hormonized. Stress of fish caused low of humoral and seluler immunity respons (phagocytic). The followed stress intensity could caused fish development that could be looked for by physiological respons. Physiological respons to stress could be grouped to two such as primary respons that include early neuroendocrine, including catecholamine released from chromaffin tissue (Randall and Perry, 1992), and hypothalamus - hypophyse - interrenal with peak in corticosteroide released to circulation (Wendelaar, 1997; Mommsen et al., 1999). Secondary respons including in plasma changed and ion tissue and metabolisme level, hematological figure, and hot-shock or proteine total decreased, all of them corelated with physiological adaptation such as in metabolism, respiration, acid-alcaline state, hydromineral balancing, immunity function and cellular respons immune (Iwama et al., 1997,1998 ; Mommsen et al., 1999).

\section{Conclusions}

Monogenean ectoparasites prevalence in African catfish in Laban Village, Menganti District, Gresik Regency, East Java Province with one month and three months old respecting were $23 \%$ and $9 \%$ African Catfish skin was not found parasite $(0 \%)$, whereas in gills were found $32 \%$ of monogenean ectoparasite infestation (Gyrodactylus sp. and Dactylogyrus sp.).

\section{References}

Afrianto E and Liviawaty E. 1992. Infection Control and Fish Disease. Kanisius Published, Yogyakarta.

Akinsanya B and Otubanjo OA. 2005. Helminth Parasite of Clarias gariepinus (Clariidae) in Lekki Lagoon, Lagos, Nigeria. Department of Zoology. University of Lagos. Nigeria.

Bambang C. 200o. Freshwater Fish Aquaculture. Kanisius Published, Yogyakarta.
Diab A, El - Bouhy Z and Hadi A. 2003. Prevalence of Some Cultured Fishes in Shakira, Damietta, and Fayium Governorates. Faculty of Veterinary Medicine, Zagazig University.

Esa A. 2008. Study Some Ectoparasite Diseases of Catfish (Clarias gariepinus) with their control by Ginger; Zingiber officiale. Parasitological Unit Fish Disease Research Department, Animal Health Research Institute, Egypt.

Ghufran M. 2004. Infection Control and Fish Disease. Rineka Cipta. Jakarta. 89-123.

Hariyadi A. 2006. Helminth Infestation Mapping and Zoonosis Risk in Marine Fish in South Indonesian Waters. School of Post Graduate. Bogor Agriculture Institute.

Hendriana A. 2010. Catfish Growing in Canvas Pond. Penebar Swadaya. Depok.

Iwama GK, Pickering AD, Sumpter JP and Schreck CB . 1997. Stress Fish and Healthy in Aquaculture. Soc. Exp. Biol. Sem. Ser. 62. University of Cambridge.

Irianto, A. 2005. Fish Pathology Telesoi Fish. Gadjah Mada University Press. Yogyakarta.

Murugaian,P. 2008. Effect of Temperature on The Behavioural and Physiological Responses of Catfish, Mystus gulio (Hamitto). Departement of Biotechnology, Vinyaka Missions University.

Mommsen TP, Vijayan MM and Bulan TW. 1999. Cortisol in teleosts: Dynamic, Action Mecanism and Metabolic regulation. Fish 9: 211 268.

Noga EJ. 200o. Fish Disease: Treatment and Diagnosis. North Carolina State University. College of Veterinary Medicine. Iowa State Press. USA.

Randall DJ and Perry SF. 1992. Catecholamine. In: Fish Physiology. WS and DJ Randall Hoar (eds.), 12B: 255-300. Academic Press, New York. 
Reed P, Francis-Flyod R and Klinger RE. 2005. Monogenean Parasite of Fish. University of Florida.

Reddy PK and Leatherland JF. 1998. Stress Physiology. Department of Biomedical Sciences. Ontario Veterinary College, University of Guelph. Canada.
Sri Subekti B and Mahasri G. 2010. Parasit and Fish Disease (Trematodiasis and Cestodiasis) Global Persada Press, Surabaya.

Usni A, Juansyah R and Eko P. 2010. Problem solving of African Catfish (Clarias gariepinus). Penebar Swadaya. Depok.

Wendelaar Bonga SE. 1997. Respons Stress in Fish. Physiol. Rev, 77: 591-625. 